\title{
IMPLEMENTASI INTRUSION DETECTION SYSTEM MENGGUNAKAN ALGORITMA BLOWFISH Studi Kasus DI DOTA CAFE
}

\author{
Doli Hasibuan ${ }^{1}$, Jimmy F. Naibaho ${ }^{2}$, Christian P. Simanjuntak ${ }^{3}$ \\ 1,2,3 Fakultas Ilmu Komputer, Universitas Methodist Indonesia \\ hasibuan.doli@gmail.com
}

\begin{abstract}
Cryptography is the study of system security, where the system needs to be secured from interference or threats from irresponsible parties. In everyday life, fraud is often found in important data, one of which is cashier system data. To prevent and overcome this, the concept of network security with the Blowfish Algorithm will be applied. One of the cryptographic algorithms is the Blowfish Algorithm. The Blowfish algorithm is quite simple but strong enough because it has a long key space, making it difficult to attack. Unexpected things often occur such as foreign parties who want to enter the system by repeatedly trying the possible username and password, or foreign parties changing the data in the cash register at Dota Café. This system will function to monitor system activity, in this case if the system feels a threat or system disturbance is found.
\end{abstract}

Keywords: Cryptography, Blowfish, IDS

\section{PENDAHULUAN}

Kebutuhan keamanan dalam bertransaksi atau berkomunikasi dalam jaringan komunikasi digital, saat ini menjadi kebutuhan yang mendasar. Dalam perkembangan Teknologi Komunikasi dan Informasi, semua layanan semakin mudah dan cepat, Seiring dengan meningkatnya penggunaannya dalam kehidupan sehari-hari, tingkat kejahatan dalam teknologi informasi digital juga meningkat. Kejahatan teknologi yang sering dijumpai saat ini seperti pencurian data, merusak data ataupun jaringan oleh pihak-pihak yang tidak bertanggungjawab, yang menimbulkan kerugian secara materi maupun non-materi.

Kriptografi merupakan ilmu yang mempelajari tentang keamanan sistem, dimana sistem perlu diamankan dari gangguan atau ancaman dari pihak-pihak yang tidak bertanggung jawab. Salah satu algoritma kriptografi adalah Algoritma Blowfish. Algoritma ini cukup sederhana namun cukup kuat karena memiliki ruang kunci yang panjang, sehingga sulit untuk diserang. Dalam keseharian, sering ditemukan kecurangan-kecurangan pada data-data penting, salah satunya data sistem kasir. Untuk mencegah dan menanggulangi hal tersebut, akan di terapkan konsep keamanan jaringan dengan Algoritma Blowfish.

Sistem ini akan berfungsi untuk memantau aktivitas sistem, dalam hal ini jika sistem merasa ditemukan ancaman atau gangguan sistem. Salah satu bentuk terjadi gangguan seperti ada nya pihak asing (tidak memiliki hak akses) yang ingin masuk ke sistem dengan mencoba berulang-ulang kemungkinan username dan password, atau adanya pihak asing yang mengganti data. Berdasarkan kejadian dan pengalaman tersebut, dibutuhkan sebuah mekanisme yang mampu memantau aktivitas sistem dan dilakukan penelitian dengan judul "Implementasi Intrusion Detection System Menggunakan Algoritma Blowfish, dengan studi kasus dilakukan di Dota Café. Penelitian ini diharapkan dapat membantu dalam penanggulangan atau mencegah terjadinya kecurangan/gangguan dari pihak yang tidak bertanggung jawab.

\section{TINJAUAN PUSTAKA}

Kriptografi

Kriptografi berasal dari dua kata bahasa Yunani, Cryptos dan Graphein. Cryptos berarti secret (rahasia) dan Graphia berarti writing (tulisan). Jadi, kriptografi berarti secret writing (tulisan rahasia). Menurut terminologinya, kriptografi adalah ilmu dan seni untuk menjaga keamanan pesan ketika pesan dikirim dari suatu tempat ke tempat lain. (Ariyus, 2008).

Kriptografi adalah ilmu dan seni dalam mengamankan pesan dengan cara mengubah pesan menjadi sesuatu yang tidak dapat dimerngerti oleh orang lain dengan teknik-teknik dan metode-metode tertentu. Kriptografi tidak berarti hanya memberikan keamanan informasi saja, namun lebih ke arah teknik-tekniknya.

\section{Algoritma Kriptografi}

Algoritma adalah urutan langkah-langkah logis untuk menyelesaikan suatu masalah yang disusun secara sistematis (Munir, 2006).Langkah-langkah tersebut harus logis, ini berarti nilai kebenarannya harus dapat ditentukan benar atau salah.

Algoritma Simetris

Algoritma simetris adalah algoritma kriptografi yang menggunakan kunci enkripsi yang sama dengan kunci 
dekripsinya. Algoritma ini mengharuskan pengirim dan penerima menyetujui suatu kunci tertentu sebelum mereka saling berkomunikasi. Keamanan algoritma simetris tergantung pada kunci, membocorkan kunci berarti bahwa orang lain dapat mengenkripsi dan mendekripsi pesan.

Agar komunikasi tetap aman, kunci harus tetap dirahasiakan. Algoritma simetris sering juga disebut dengan algoritma kunci rahasia, algoritma kunci tunggal, atau algoritma satu kunci.

\section{Algoritma Asimetris}

Algoritma asimetris, sering juga disebut dengan algoritma kunci publik, menggunakan dua jenis kunci, yaitu kunci publik (public key) dan kunci rahasia (secret key). Kunci publik merupakan kunci yang digunakan untuk mengenkripsi pesan.

Sedangkan kunci rahasia digunakan untuk mendekripsi pesan. Kunci publik bersifat umum, artinya kunci ini tidak dirahasiakan sehingga dapat dilihat oleh siapa saja. Sedangkan kunci rahasia adalah kunci yang dirahasiakan dan hanya orang-orang tertentu saja yang boleh mengetahuinya. Keuntungan utama dari algoritma ini adalah memberikan jaminan keamanan kepada siapa saja yang melakukan pertukaran informasi meskipun di antara mereka tidak ada kesepakatan mengenai keamanan pesan terlebih dahulu maupun saling tidak mengenal satu sama lainnya.

\section{Algoritma Blowfish}

Blowfish diciptakan oleh seorang Cryptanalyst bernama Bruce Schneier, Presiden perusahaan Counterpane Internet Security, Inc (Perusahaan konsultan tentang kriptografi dan keamanan komputer) dan dipublikasikan tahun 1994. Dibuat untuk digunakan pada komputer yang mempunyai microposesor besar (32-bit keatas dengan cache data yang besar). Blowfish merupakan algoritma yang tidak dipatenkan dan license free, dan tersedia secara gratis untuk berbagai macam kegunaan.

\section{Intrusion Detection System}

IDS (Intrusion Detection System) adalah sebuah sistem yang melakukan pengawasan terhadap traffic jaringan dan pengawasan terhadap kegiatan-kegiatan yang mencurigakan didalam sebuah sistem jaringan. Jika ditemukan kegiatankegiatan yang mencurigakan berhubungan dengan traffic jaringan maka IDS akan memberikan peringatan kepada sistem atau administrator jaringan.

\section{Short Message Service}

SMS (Short Message Service) atau layanan pesan singkat mempunyai sejarah tersendiri sebagai media layanan yang paling meledak abad ini. Awalnya SMS berfungsi untuk memberikan layanan pengiriman pesan teks singkat antar perangkat mobile phone (telepon genggam).

SMS sebenarnya hanya layanan tambahan terhadap dua layanan utama (layanan voice dan switched data) dalam sistem jaringan komunikasi GSM, namun karena keberhasilan SMS yang tidak terduga dengan ledakan pelanggan yang mempergunakannya, menjadikan SMS sebagai bagian integral dari layanan sistem standar standar komunikasi lainnya seperti CDMA, UMTS, bahkan jaringan telepon rumah (fixed phone) juga mengadopsi teknologi yang sebenarnya sangat sederhana ini.

\section{SMS Gateway}

SMS Gateway adalah sebuah perangkat yang menawarkan layanan transit SMS, mentransformasikan pesan ke jaringan selular dari media lain, atau sebaliknya, sehingga memungkinkan pengiriman atau penerimaan pesan SMS dengan atau tanpa menggunakan ponsel.(Wikipedia). Sebagaimana penjelasan diatas, SMS Gateway dapat terhubung ke media lain seperti perangkat SMSC dan server milik Content Provider melalui link IP untuk memproses suatu layanan SMS.

\section{Gammu}

Gammu merupakan sebuah aplikasi untuk membangun SMS Gateway. Aplikasi tersebut saat ini dikelola oleh Michal Cihar dan orang orang yang berpengalaman dalam membuat aplikasi Gnokii dan MyGnokii (Gammu Project, 2009). Gammu memiliki kemampuan menjalankan layanan antara lain calls, SMS, EMS, phonebook memories, filesystem, logos, pictures, ringtones, dan lainlain (Masruri, 2015).

\section{Jaringan Komputer}

Jaringan komputer adalah sekumpulan peralatan atau komputer yang saling dihubungkan untuk berbagi sumber daya (Anjik, 2008). Agar terjadi jaringan antar komputer maka setiap bagian dari jaringan komputer meminta dan memberikan layanan (servis). Pihak yang meminta layanan disebut client dan yang memberi layanan disebut server.

\section{MySQL}

Sistem manajemen database SQL yang bersifat Open Source dan paling populer saat ini, dapat dipakai oleh siapa saja tanpa membayar dan source code-nya bisa diunduh oleh siapa saja. Sistem database MySQL mendukung beberapa fitur seperti multithreaded, multiuser, dan SQL database managemen sistem (DBMS). Database ini dibuat untuk keperluan sistem database yang cepat, handal dan mudah digunakan.

Personal Home Page (PHP)

Personal Home Page (PHP) merupakan kependekatan dari kata Hypertextpreprocessor. PHP tergolong sebagai perangkat lunak open source yang diatur dalam aturan General Purpose Lincences (GPL) dan tergolong sebagai bahasa pemograman yang berbasis server (server side scripting). Pemograman PHP sangat cocok dikembangkan dalam lingkungan web, karena PHP bisa diletakan pada script HTML atau sebaliknya.

\section{Web server Apache}

Web server adalah sebuah program yang berfungsi untuk menerima dan mengelolah permintaan browser Web.Apabila dalam pernyataan terdapat kode-kode PHP,server web akan mengirim ke server aplikasi PHP untuk diolah dan hasilnya berupa halaman HTML dan kemudian dikirim kembali ke server web, kemudian kode HTML akan diteruskan oleh server web untuk ditampilkan di browser.saat ini umumnya web server telah dilengkapi 
dengan aplikasi mesin penrjemah scrip yang memungkinkan server web menyediakan layanan situs web dinamis dengan memanfaatkan pustaka tambahan seperti ASP dan PHP.

\section{Web Browser}

Web browser adalah aplikasi perangkat lunak yang digunakan untuk mengambil dan menyajikan sumber informasi web. Sumber informasi web diidentifikasi dengan Uniform Resource Identifier (URL) yang dapat terdiri dari halaman web, video, gambar, ataupun konten lainnya. Antara lain Google Inc, merilis web browser dengan nama Google Chrome.

\section{ANALISIS DAN PERANCANGAN}

\section{Analisis Sistem}

Pada Dota Café sudah diterapkan sistem untuk transaksi penjualan makanan dan minuman. Sistem kasir pada dota café sama seperti sistem transaksi pada café pada umumnya, yaitu melakukan transaksi dari setiap menu yang dipesan pelanggan. Namun hal yang perlu diperhatikan menyangkut sistem transaksi penjualan tersebut adalah keamanan data keuangan. Sering ditemukan kecurangan-kecurangan pada data-data penting, salah satunya data yang menyangkut penjualan misalnya laporan tidak Untuk mencegah dan menanggulangi hal tersebut, akan di terapkan konsep keamanan jaringan dengan Algoritma Blowfish.Selain itu, sering terjadinya hal-hal yang tidak terduga seperti pihak asing yang ingin masuk ke sistem dengan mencoba berulang-ulang kemungkinan username dan password, atau adanya pihak asing yang mengganti data dalam mesin kasir pada Dota Café.

\section{Perancangan Sistem}

Disain Tabel

Perancangan tabel untuk membangun sistem ini dapat dirincikan sebagai berikut :

a. Tabel Admin, memiliki id_admin sebagai Primary Key, dapat dilihat pada Tabel 4.1.

\section{Tabel 4.1. Tabel Admin}

\begin{tabular}{|c|c|c|c|}
\hline No & Nama Field & Tipe Data & Panjang \\
\hline 1 & Id_Admin $(*)$ & Integer & 11 \\
\hline 2 & Nama_admin & Varchar & 60 \\
\hline 3 & Jenkel & Varchar & 15 \\
\hline 4 & Username & Varchar & 30 \\
\hline 5 & Password & Varchar & 30 \\
\hline 6 & Akses & Varchar & 35 \\
\hline b. Tabel Menu, memiliki id_menu sebagai Primary
\end{tabular}

Key, dapat dilihat pada Tabel 4.2.

Tabel 4.2. Tabel Menu

\begin{tabular}{|c|c|c|c|}
\hline No & Nama Field & Tipe Data & Panjang \\
\hline 1 & Id_menu (*) & Integer & 11 \\
\hline 2 & nama_menu & Varchar & 90 \\
\hline
\end{tabular}

\begin{tabular}{|c|c|c|c|}
\hline 3 & Jenis_menu & Varchar & 30 \\
\hline 4 & Harga & Varchar & 30 \\
\hline 5 & Status_menu & Varchar & 15 \\
\hline
\end{tabular}

c. Tabel Meja

Tabel meja memiliki id_meja sebagai Primary Key, dapat dilihat pada Tabel 4.3.

Tabel 4.3. Tabel Meja

\begin{tabular}{|c|c|c|c|}
\hline No & Nama Field & $\begin{array}{c}\text { Tipe } \\
\text { Data }\end{array}$ & Panjang \\
\hline 1 & Id_meja(*) & Integer & 11 \\
\hline 2 & Nama_meja & varchar & 11 \\
\hline 3 & Status_meja & Text & \\
\hline
\end{tabular}

d. Tabel Faktur

Tabel Faktur memiliki id_faktur sebagai Primary Key, dapat dilihat pada Tabel 4.4.

Tabel 4.4. Tabel Faktur

\begin{tabular}{|c|c|c|c|}
\hline No & Nama Field & $\begin{array}{c}\text { Tipe } \\
\text { Data }\end{array}$ & Panjang \\
\hline 1 & Id_faktur $(*)$ & Integer & 11 \\
\hline 2 & Id_admin & Integer & 11 \\
\hline 3 & Tgl_faktur & Date & \\
\hline 4 & Total_faktur & Varchar & 11 \\
\hline 5 & Cash & Varchar & 11 \\
\hline 6 & Status_faktur & Varchar & 30 \\
\hline
\end{tabular}

e. Tabel Jual

Tabel jual memiliki id_jual sebagai Primary Key, dapat dilihat pada Tabel 4.5.

Tabel 4.5. Tabel Jual

\begin{tabular}{|c|c|c|c|}
\hline No & Nama Field & Tipe Data & Panjang \\
\hline 1 & Id_jual $(*)$ & Integer & 11 \\
\hline 2 & Id_faktur & Integer & 11 \\
\hline 3 & Id_admin & Integer & 11 \\
\hline 4 & Id_meja & Integer & 11 \\
\hline 5 & Id_menu & Integer & 11 \\
\hline 6 & Tgl_jual & Date & \\
\hline 7 & Qty & Varchar & 10 \\
\hline 9 & Total & Varchar & 10 \\
\hline
\end{tabular}

f. Tabel Kom

Tabel kom memiliki id_kom sebagai Primary Key, dapat dilihat pada Tabel 4.6.

Tabel 4.6. Tabel Kom

\begin{tabular}{|c|c|c|c|}
\hline No & Nama Field & Tipe Data & Panjang \\
\hline 1 & Id_kom $(*)$ & Integer & 11 \\
\hline 2 & Mac & Text & 11 \\
\hline 3 & Akses & Varchar & 30 \\
\hline
\end{tabular}


g. Tabel Rekam

Tabel rekam memiliki id_rekam sebagai Primary

Key, dapat dilihat pada Tabel 4.7.

Tabel 4.7 Tabel Rekam

\begin{tabular}{|c|c|c|c|}
\hline No & Nama Field & Tipe Data & Panjang \\
\hline 1 & Id_rekam $(*)$ & Integer & 11 \\
\hline 2 & Ip & Varchar & 20 \\
\hline
\end{tabular}

\begin{tabular}{|c|c|c|c|}
\hline 3 & Tgl_rekam & Timestamp & \\
\hline 4 & Status_rekam & Text & \\
\hline
\end{tabular}

Berikut ini dapat ditunjukkan diagram konteks dari sistem yang dirancang yang melibatkan konsumen, administrasi dan pimpinan. Rincian dapat dilihat pada gambar 1 berikut ini.

\section{Data Flow Diagram :}

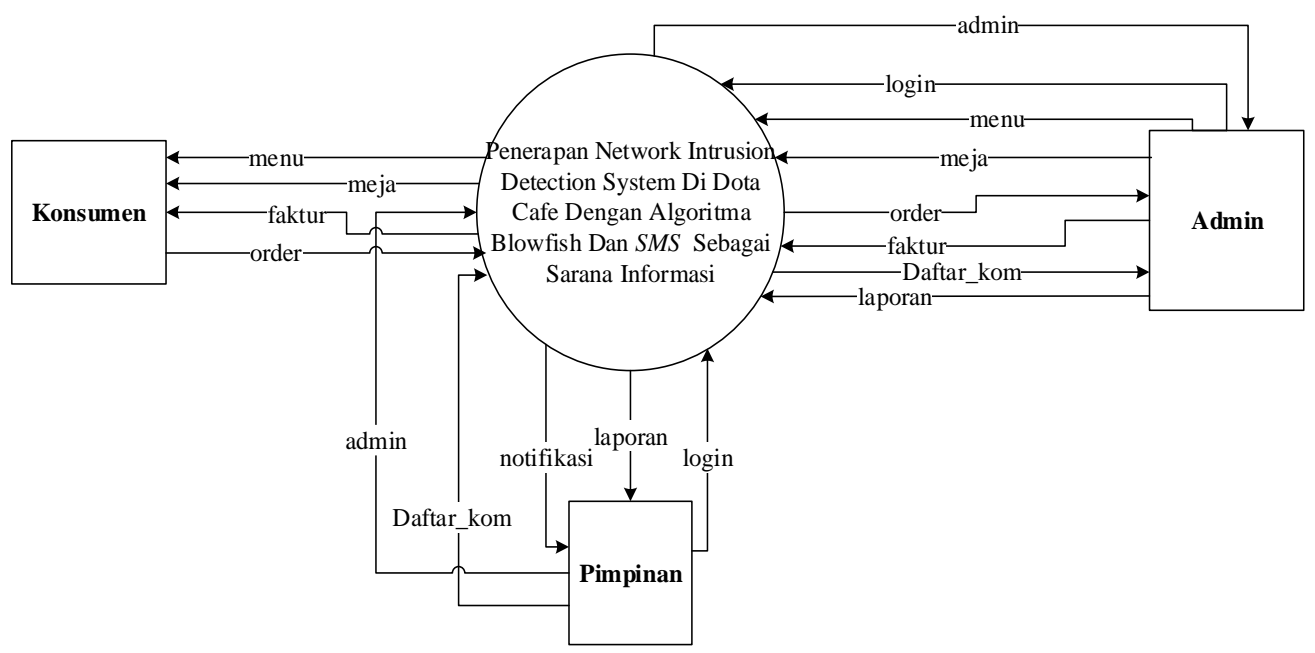

Gambar 1. Diagram Konteks

\section{HASIL DAN PEMBAHASAN}

\section{Tampilan Antarmuka Admin}

a. Tampilan Form Home

Home merupakan tampilan awal ketika website diakses. Tampilan Form Home dapat dilihat pada Gambar 2.
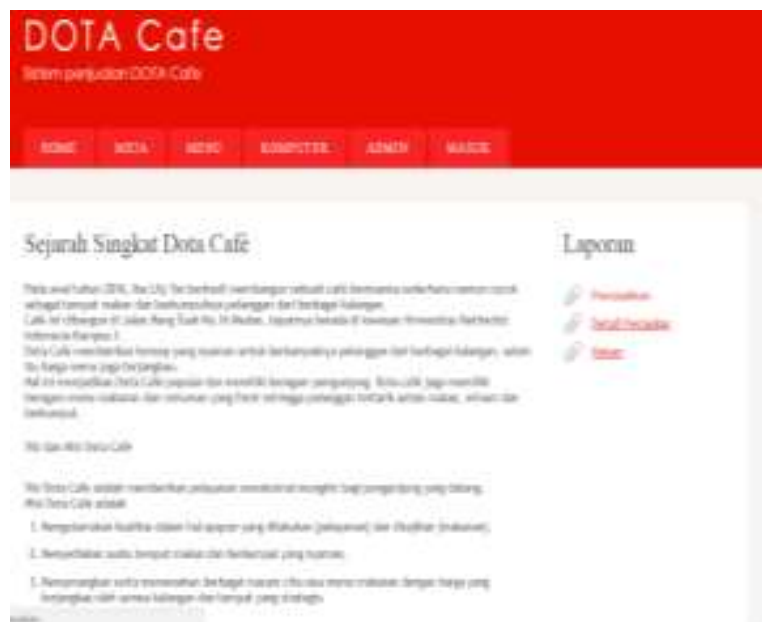

Gambar 2. Tampilan Form Home b. Tampilan Form Login

Tampilan Form Login berguna untuk melakukan login menggunakan username, password serta level Admin sebagai pimpinan. Tampilan Form Login dapat dilihat pada Gambar 3.

\section{Masuk Sistem}

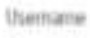

Fanuert

Gambar 3. Form Login

c. Tampilan Form Data Meja

Tampilan Form Data meja akan menampilkan data-data meja yang sudah disimpan di dalam database. Tampilan Form Data Lapangan dapat dilihat pada Gambar 4.

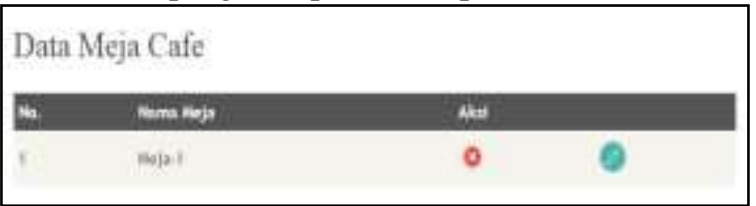

Gambar 4. Form Data Meja 
d. Tampilan Form Data Menu Café

Tampilan Form ini berfungsi untuk menampilkan data menu café dota. Tampilan Form Data Menu Café dapat dilihat pada Gambar 5

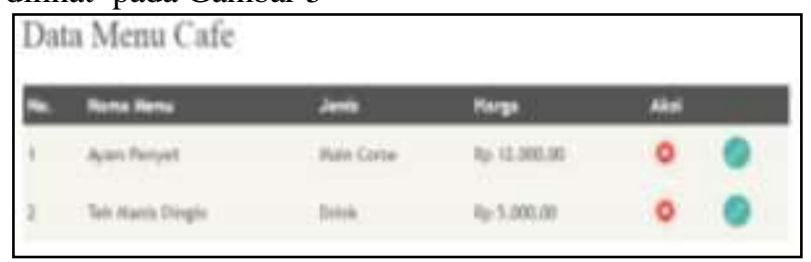

Gambar 5. Form Data Menu Café

e. Tampilan Form Tambah Data Menu Café

Tampilan Form ini berfungsi untuk menambah data menu café dota. Tampilan Form Tambah Data Menu Café dapat dilihat pada Gambar 6

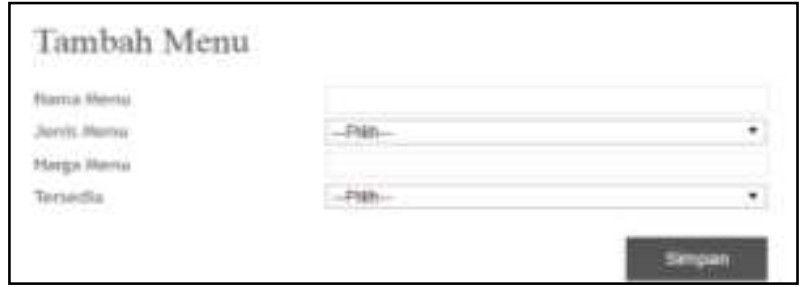

Gambar 6. Form Tambah Data Menu Café

f. Tampilan Form Data Komputer Client

Tampilan Form ini berfungsi untuk menampilkan data komputer client. Tampilan Form Data Komputer Client dapat dilihat pada Gambar 7.

\section{Data Komputer Klien}

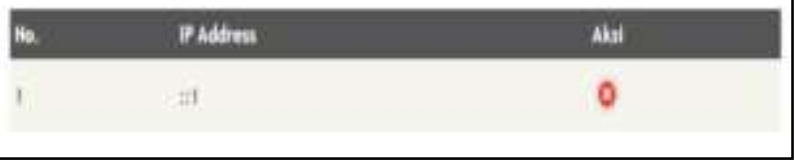

Gambar 7. Form Data Komputer Client

g. Tampilan Form Laporan Pemasukan

Tampilan Form ini berfungsi untuk menampilkan data laporan pemasukan. Tampilan Form Laporan Pemasukan dapat dilihat pada Gambar 8.

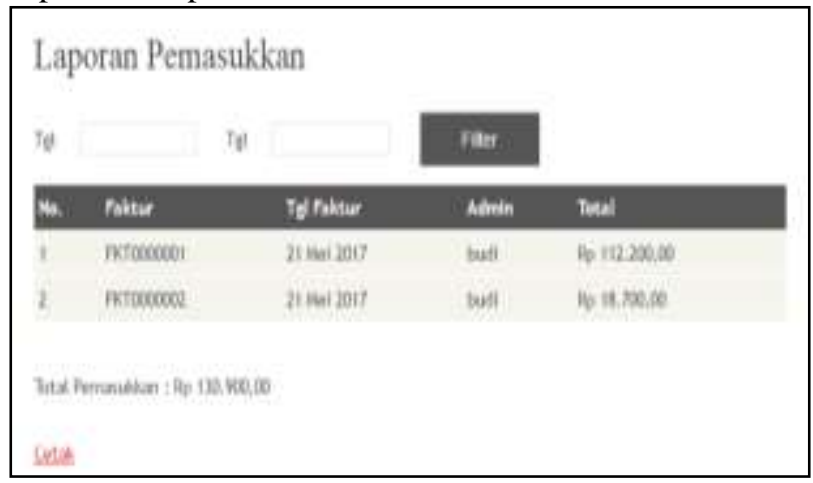

Gambar 8. Form Laporan Pemasukan

h. Tampilan Form Laporan Detail Pemasukan
Tampilan Form ini berfungsi untuk menampilkan data laporan detail pemasukan. Tampilan Form Laporan Detail Pemasukan dapat dilihat pada Gambar 9.

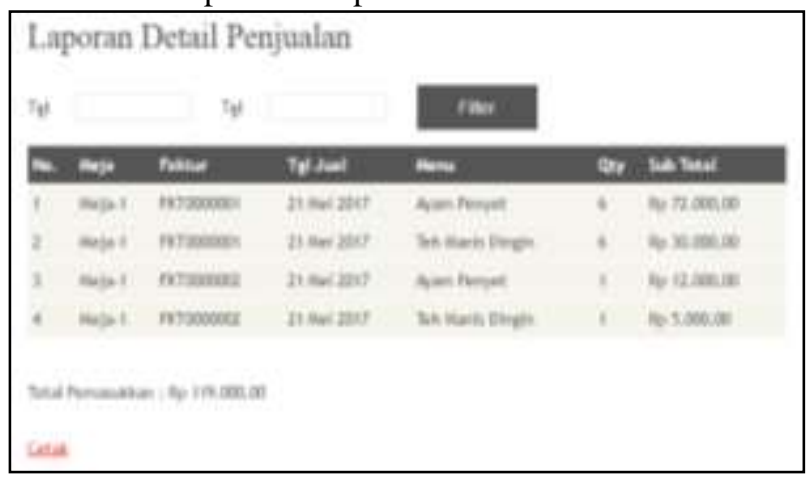

Gambar 9 Form Laporan Detail Pemasukan

i. $\quad$ Tampilan Form Laporan Rekam Aktivitas Tampilan Form ini berfungsi untuk menampilkan laporan rekam aktivitas. Tampilan Form Laporan Rekam Aktivitas dapat dilihat pada Gambar 10.

\begin{tabular}{|c|c|c|c|}
\hline \multicolumn{4}{|c|}{ Laporan Rekam Aktivitas } \\
\hline Tal & & & \\
\hline Mo. & IP ADQRESS & Tareseal & Sentus \\
\hline 1 & 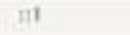 & 27 Hei 2017 & SEBVEI LOGOUT \\
\hline 2 & $7 t$ & 27 Mel 2017 & SONER LOGIN \\
\hline 3 & III & 22 Met 2007 & SEINEH LOGOU \\
\hline 4 & 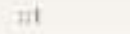 & 27 Hei 20017 & CLET LOGIN \\
\hline 5 & it & 22 Mel 2017 & CHEAT LOSOUT \\
\hline 6 & xit & 22 Mel 2017 & SEINEHLOGIH \\
\hline 7 & सा & 22 Meizor & SEDERLOGOU \\
\hline A & \pm 1 & 26 Mes 2007 & SEOELL LOGHA \\
\hline 9 & III & $2 \mathrm{H}$ Meri2017 & СLEHT LOCIH \\
\hline 10 & if & 28 Mer 2017 & CUEAT Locourt \\
\hline 11 & til & 28 Meizont & STHER LOCIB \\
\hline 18 & मा & 30 Mer 2017 & CLEAT LOCOU \\
\hline 1) & 19 & 30 Mei 2017 & CHEHT LOCIN \\
\hline 14 & $\mathrm{nt}$ & 31 Merizon & STINER LOGIN \\
\hline 15 & at & 31 Mes 2017 & SEIMER LOGOUT \\
\hline is & it & 31 Heiza1? & SENER LOGIK \\
\hline
\end{tabular}

Gambar 10. Form Laporan Rekam Aktivitas

j. Tampilan Notifikasi melalui SMS

Tampilan Notifikasi melalui SMS ini berfungsi untuk menampilkan sms yang berisi notifikasi bahwa client masuk dan keluar dari halaman website.

Tampilan Form Notifikasi Client Masuk dapat dilihat pada Gambar 11. 


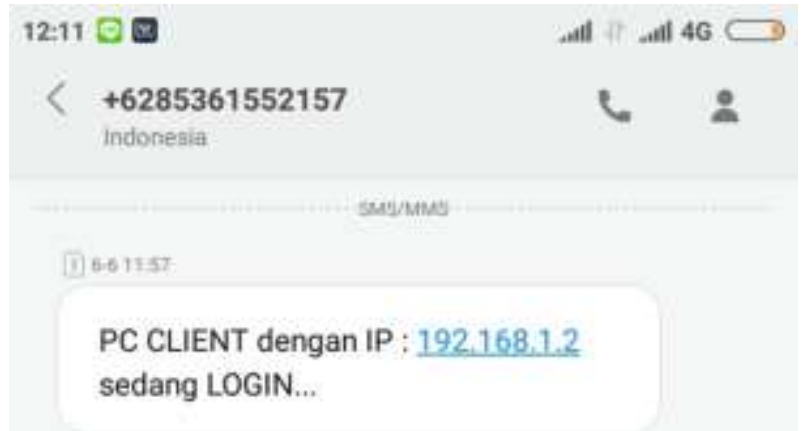

Gambar 11. Form Notifikasi Client Masuk

- Tampilan Form Notifikasi Client Keluar jika keluar dari halaman Client dapat dilihat pada Gambar 12 berikut :

\section{$12: 12$ 웅}

$+6285361552157$

indonesia

[1] 6.6 $13: 18$

\section{PC CLIENT dengan IP : 192.168 .1 .2 Sudah LOGOUT...}

Gambar 12. Notifikasi Client Keluar

- Tampilan Notifikasi Deteksi PC Asing jika terdapat PC dengan IP tidak terdaftar masuk ke halaman Client dapat dilihat pada Gambar 13 berikut :

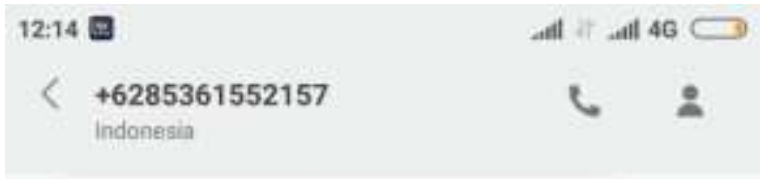

\section{Ada PC dengan IP : 192.168 .1 .2} mencoba masuk ke halaman CLIENT Tanggal : 2017-06-06 09:10:23

\section{Gambar 13. Notifikasi Deteksi PC Asing}

- Tampilan Form Notifikasi Deteksi Server jika masuk ke halaman Client dapat dilihat pada Gambar 14 berikut :

\section{2:15 몽}

\section{< +6285361552157}

Indonesin

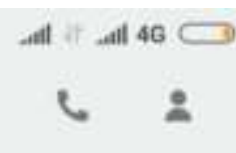

Ada PC dengan IP : :1, mencoba masuk ke halaman CLIENT Tanggal : 2017-06-06 09:11:10

Gambar 14. Notifikasi Deteksi Server

\section{Tampilan Antarmuka Operator Kasir}

a. Tampilan Form Home

Home merupakan tampilan awal ketika website diakses. Tampilan Form Home dapat dilihat pada Gambar 15.

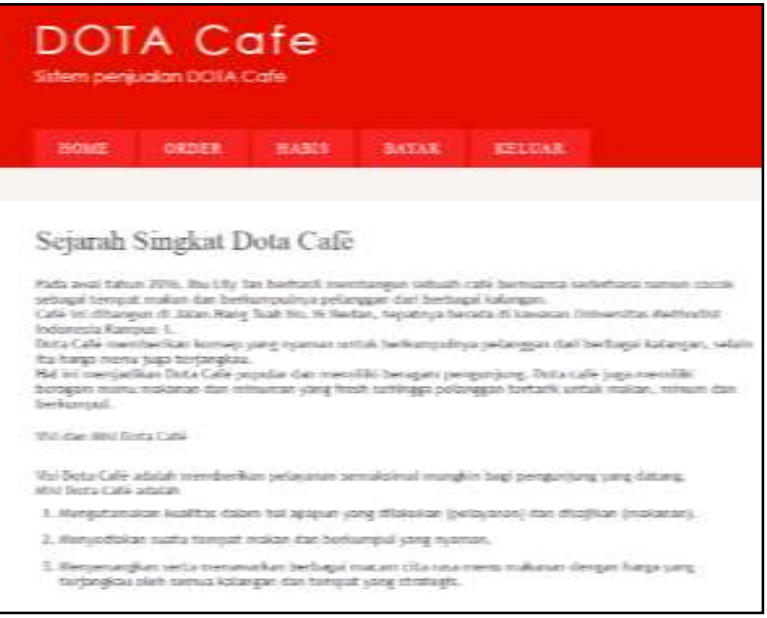

Gambar 15. Tampilan Form Home

b. Tampilan Form Order Menu

Tampilan Form Order Menu merupakan tampilan untuk order menu konsumen. Tampilan Form Order Menu dapat dilihat pada Gambar 16.

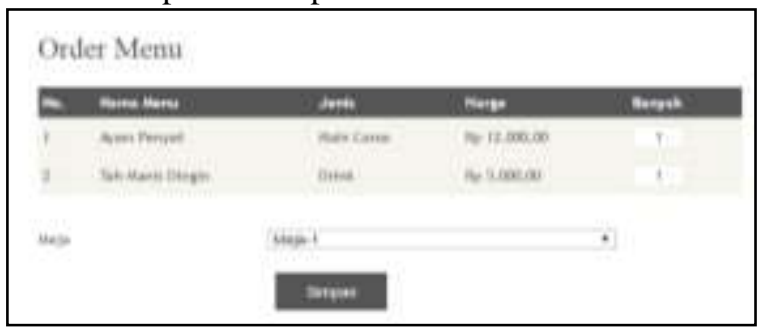

Gambar 16. Tampilan Form Order Menu

c. Tampilan Form Bayar

Tampilan Form Bayar merupakan tampilan list meja yang sudah melakukan order menu. Tampilan Form Bayar dapat dilihat pada Gambar 17.

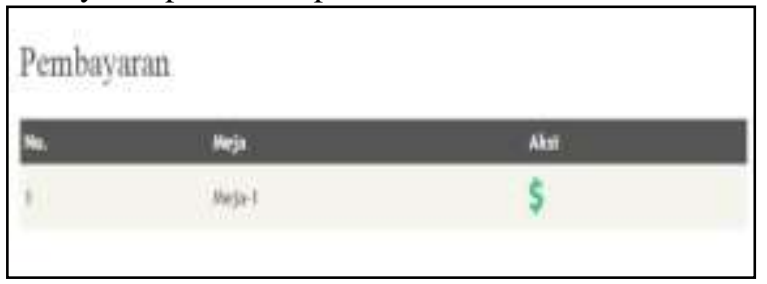

Gambar 17. Tampilan Form Bayar

d. Tampilan Form Hitung Pembayaran

Tampilan Form Hitung Pembayaran merupakan tampilan untuk menghitung pembayaran menu yang sudah di order konsumen. Tampilan Form Hitung Pembayaran dapat dilihat pada Gambar 18. 


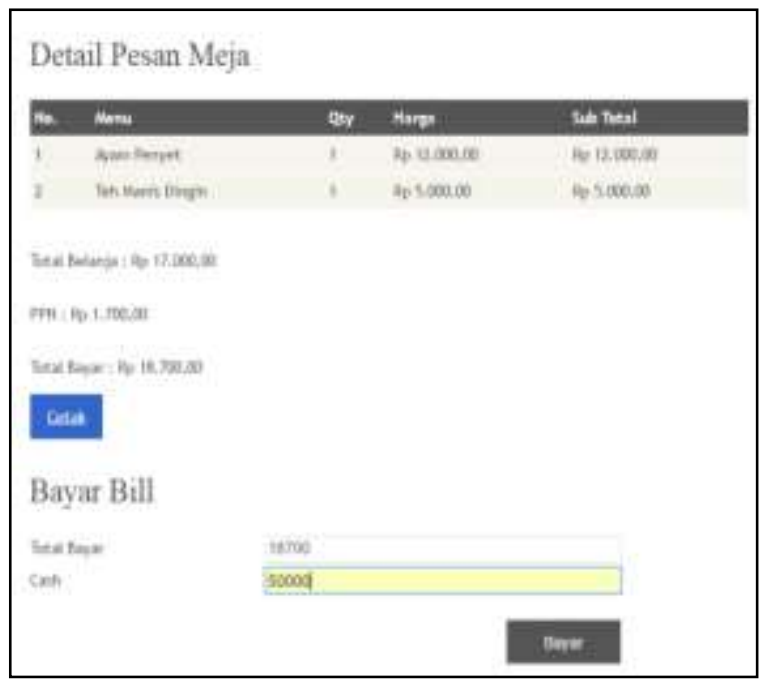

Gambar 18 Form Hitung Pembayaran

e. Tampilan Form Faktur Pembayaran

Tampilan Form Faktur Pembayaran merupakan tampilan untuk menampilkan faktur pembayaran mеnu yang sudah di bayar konsumen. Tampilan Form Faktur Pembayaran dapat dilihat pada Gambar 19.

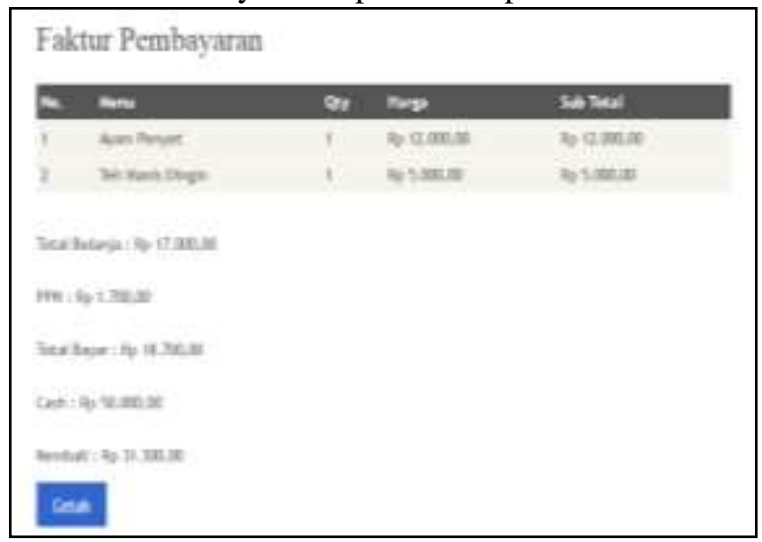

Gambar 19. Faktur Pembayaran

\section{KESIMPULAN}

Kesimpulan dari sistem ini adalah sebagai berikut:

1. Pada sistem diterapkan konsep kriptografi algoritma Blowfish dan menggunakan bahasa pemrograman PHP dengan database MySQL.

2. Penelitian ini membahas tentang pemantauan aktivitas sistem, seperti berupa ancaman dan gangguan/error pada sistem dengan menerapkan konsep Intrusion Detection System.

3. Sistem ini diterapkan pada jaringan internal Dota Café.

4. Dengan adanya sistem yang dirancang ini, sistem Dota Café menerapkan algoritma Blowfish sebagai metode untuk mengamankan data.

5. Adanya SMS Gateway yang bermanfaat sebagai sarana informasi.
6. Sistem memberikan peningkatan keamanan data pada Dota Café.

7. Sistem membantu pemilik mengetahui terjadinya kecurangan/gangguan pada sistem melalui informasi berupa SMS yang dikirim otomatis.

8. Sistem ini secara tidak langsung mampu meningkatkan kinerja sistem pada Dota Café.

\section{REFERENSI}

[1]. Abdiansah. 2009. Membangun SMS-Gateway Untuk Pengisian Pulsa Elektronik Berbasis Web. Jurnal Sistem Informasi (JSI), Vol. 1, No. 2

[2]. Anam, Khoirul, 2010, Manajemen Bandwidth Menggunakan Router Mikrotik di Dinas Pendidikan Pemuda dan Olahraga Kota Pekalongan, Sekolah Tinggi Manajemen Informatika dan Komputer Widya Pratama Pekalongan, Pekalongan.

[3]. Anjik Sukmanji, Rianto. 2008. Jaringan Komputer. C.V. ANDI OFFSET (Penerbit ANDI). Yogyakarta.

[4]. Ariyus, Dony. 2007. Intrusion Detection System. Yogyakarta : Penerbit Andi

[5]. Fathansyah, 2012, Basis Data, Bandung: Informatika.

[6]. Hartono, Jogianto. 2011. Sistem Informasi. Andi, Yogyakarta

[7]. Ibrahim, Ali. 2011. Pengembangan Sistem Informasi Monitoring Tugas Akhir Berbasis Short Message Service (SMS) Gateway di Fasilkom UNSI. Ogan Ilir:JUSI. Vol.1, No. 2

[8]. Indrajani, 2011.Perancangan Basis Data Dalam All in 1. Jakarta: PT. Elex Media Komputindo

[9]. Kadir,Abdul. 2009. Mudah mempelajari database MySQL. Andi, Yogyakarta

[10].Kadir, Abdul. 2010. Pengenalan Sistem Informasi. Andi. Yogyakarta

[11].Kadir, Abdul. 2014. Dasar Pemrograman Web Dinamis MenggunakanPHP. Penerbit Andi : Yogyakarta. 